University of Nebraska - Lincoln

DigitalCommons@University of Nebraska - Lincoln

1998

\title{
Population Growth of Rhinocyllus conicus (Coleoptera: Curculionidae) on Two Species of Native Thistles in Prairie
}

Svata M. Louda

University of Nebraska - Lincoln, slouda1@unl.edu

Follow this and additional works at: https://digitalcommons.unl.edu/bioscilouda

Part of the Ecology and Evolutionary Biology Commons

Louda, Svata M., "Population Growth of Rhinocyllus conicus (Coleoptera: Curculionidae) on Two Species of Native Thistles in Prairie" (1998). Svata M. Louda Publications. 27.

https://digitalcommons.unl.edu/bioscilouda/27

This Article is brought to you for free and open access by the Papers in the Biological Sciences at DigitalCommons@University of Nebraska - Lincoln. It has been accepted for inclusion in Svata M. Louda Publications by an authorized administrator of DigitalCommons@University of Nebraska - Lincoln. 
PopUlation ECOLOGY

\title{
Population Growth of Rhinocyllus conicus (Coleoptera: Curculionidae) on Two Species of Native Thistles in Prairie
}

\author{
SVAŤA M. LOUDA
}

School of Biological Sciences and Cedar Point Biological Station, University of Nebraska, Lincoln, NE 68588-0118

\begin{abstract}
Environ. Entomol. 27(4): 834-841 (1998)
ABSTRACT The insect Rhinocyllus conicus Froehlich is a flowerhead weevil deliberately introduced into the United States for the biological control of invasive exotic thistles in the genus Carduus. This study documents the course and magnitude of the weevil population expansion onto nontarget host plants. No weevils were reared from either Platte thistle, Cirsium canescens Nuttall, or wavyleaf thistle, C. undulatum (Nuttall) Sprengel, from 1977 to 1993 at 2 Sandhills prairie preserves: Arapaho Prairie and Niobrara Valley. For Platte thistle, the number of both $R$. conicus adults on plants and the number of larvae developing in flowerheads increased significantly from 1993 to 1996. Population growth lagged at the northcentral Niobrara Valley site, compared with the southwestern Arapaho Prairie site, but by 1996 the densities attained were similar. For wavyleaf thistle, a later flowering native species, the 1st weevils were also observed in 1993 at both sites. However, weevil densities on wavyleaf thistle grew more slowly and remained significantly lower than those on Platte thistle. The most likely hypothesis to explain the greater use of Platte thistle, compared with wavyleaf thistle at these sites, is greater phenological synchrony of its flowerhead development with $R$. conicus oviposition activity. The results suggest that inclusion of ecological characteristics, such as phenology, in prerelease studies and completion of long-term, follow-up studies on releases would improve our understanding and evaluation of risk to native species from potential biological control agents.
\end{abstract}

KEY WORDS Curculionidae, host range expansion, invasion, musk thistle, nontarget effects, risks of biological control

POPULATION GROWTH AT the beginning of a hostplant range expansion by a phytophagous insect represents a biologically important and relatively undocumented phenomenon (McEvoy 1996, Simberloff and Stiling 1996). This study quantifies the colonization and initial population growth of the weevil Rhinocyllus conicus Froehlich (Coleoptera: Curculionidae), a deliberately introduced biological control agent, on 2 novel, nontarget host plant species in midgrass sand prairie.

Based on extensive pre- and early postrelease studies of $R$. conicus oviposition, feeding, and larval growth (summarized by Zwoelfer and Harris 1984), significant use of North American Cirsium spp. by R. conicus was not expected. Stronger oviposition preference for Carduus spp. and slower larval development on Cirsium spp. were expected to select against significant transference to native North American Cirsium spp. (Zwoelfer and Harris 1984). They concluded (Zwoelfer and Harris 1984, p. 59) "It is difficult to present a convincing argument that the native thistle will not be damaged ... in practice the effects on native Cirsium spp. in Canada have been negligible ..."

The development of $R$. conicus on native, nontarget Cirsium spp. has been reported. This weevil has been reared from the flowerheads of one-third of the native Cirsium spp. in California (Pemberton et al. 1985; Goeden and Ricker 1986a, b, 1987a, b; Turner et al.
1987; Turner and Herr 1996; Palmisano and Fox 1997), from half of the 6 native thistle species in Rocky Mountain National Park, Colorado [C.centaureae (Rydberg) K. Schumann, C. scopulorum (Greene) Cockerell, and C. undulatum (Louda et al. 1997), and from C. undulatum in Montana (Rees 1977, 1991), Colorado, Nebraska, and South Dakota (Louda et al. 1997). No previous studies, however, have quantified the dynamics of $R$. conicus host range expansion and population growth on native North American Cirsium spp.

Data on the interaction of $R$. conicus with native thistles are of particular interest for 3 reasons. First, they quantify a rare event of general ecological and evolutionary interest. Second, the host range expansion onto Platte thistle, C. canescens, is of special ecological interest. Platte thistle is relatively restricted geographically to sand prairie in the central part of the Upper Great Plains (Great Plains Flora Association 1977, 1986). Inflorescence feeding by native insects limits the number of viable seeds (Lamp and McCarty $1979,1982 \mathrm{a}, \mathrm{b}$; Louda et al. 1990, 1992). And, the availability of seed limits seedling recruitment, local population density, and lifetime fitness of Platte thistle (Louda and Potvin 1995). Therefore, this is a case in which the population consequences of additional seed losses can be predicted quantitatively. Furthermore, Platte thistle is the putative progenitor for Pitcher's thistle, Cirsium pitcheri (Torrey) Torrey \& Gray, a federally listed threatened species around the Great 
Lakes (Pavlovic et al. 1992). The ecological similarities between the 2 species are impressive (Louda 1994). Inflorescence-feeding insects also reduce both seed production (Keddy and Keddy 1984) and seedling recruitment of Pitcher's thistle (unpublished data). Because both of these species are geographically restricted and seed-limited, their persistence is vulnerable to further decreases in seed reproduction. Third, the observations contribute new information for the evaluation of ecological risks associated with classical biological control. Biological control is an option for the management of invasive weeds (Louda and Masters 1993; OTA 1993, 1995), but more data are needed on potential side effects (Simberloff 1981, 1992; Howarth 1983, 1991; Karieva 1996; McEvoy 1996; Simberloff and Stiling 1996).

Thus, the specific objectives of this study were to quantify the pattern of population growth of $R$. conicus on 2 related, but ecologically different, indigenous thistles (Platte thistle and wavyleaf thistle), based on data from 2 native prairie grassland preserves over 7 growing seasons. In addition, the hypothesis that phenological synchrony influences the observed difference in use of the 2 thistles by $R$. conicus was examined.

\section{Materials and Methods}

Biology. The flowerhead weevil $R$. conicus was introduced from Europe into the United States in 1969 to limit seed production by invasive Eurasian Carduus spp. thistles, including C. nutans L. complex and $C$. acanthoides L. (Kok and Surles 1975; Rees 1977, 1991; Surles and Kok 1978). It was then introduced into Nebraska in 1972 and actively distributed throughout the state subsequently (McCarty and Lamp 1982). Redistribution of $R$. conicus in the United States continues (Boldt and Jackman 1993). In spring, overwintered adults of $R$. conicus congregate on early flowerheads, and eggs are deposited (Rees 1982). After 6-8 $\mathrm{d}$ the larvae hatch, burrow into the receptacle, feed for 25-40 d, and pupate in hardened cells within the flowerhead. The pupal stage lasts 8-14 d. A newly emerged adult remains within the pupal chamber for $\approx 2 \mathrm{wk}$ before dispersing to an overwintering site. No R. conicus were reported in several previous studies of Platte thistle (Lamp and McCarty 1979; Lamp 1982a, b; Louda et al. 1990, 1992; Louda and Potvin 1995).

Wavyleaf and Platte thistles co-occur in Sandhills prairie. The distribution of these native species is patchy, and neither is considered a serious weed (McCarty et al. 1967). Wavyleaf thistle, which has a broad geographic distribution in the plains (Great Plains Flora Association 1986), is a tap-rooted, short-lived, iterocarpic perennial in our region (McCarty et al. 1967). Flowering starts in June, peaks in July, and is completed in August. Platte thistle, which occurs in disturbances in upland prairie on sandy soils in the upper Great Plains, is more restricted. Its center of distribution is in the Sandhills formation of central Nebraska (McCarty et al. 1967, Great Plains Flora Association 1977, 1986). Platte thistle is a monocarpic perennial. Juvenile rosettes grow for $1-5 \mathrm{yr}$ before they bolt, flower, set seed, and die (Lamp and McCarty 1981, Louda and Potvin 1995). Flowering is in early-mid-May and completed by the end of June (Great Plains Flora Association 1986). Platte thistle is the earliest flowering native Cirsium in the Sandhills.

Three native insects commonly feed within the developing inflorescences of these thistles (Lamp and McCarty 1982a, b; Louda et al. 1990, 1992, Louda and Potvin 1995). The insects include: 2 tephritid flies, Paracantha culta Wiedeman and Orellia occidentale (Snow), and a pyralid moth, Homeosoma stypticellum Grote. The native species with which $R$. conicus overlaps most is $P$. culta. There are no records of any of these native insects developing within flowerheads of Carduus spp. (Lamp and McCarty 1982a, b).

The study was done at 2 Nature Conservancy preserves, $330 \mathrm{~km}$ apart: Arapaho Prairie, Arthur County, $\mathrm{NE}$, in the southwestern Sandhills and Niobrara Valley Preserve, northern Brown County, NE, in the northcentral Sandhills. Both preserves contain characteristic Sandhills prairie vegetation (Keeler et al. 1980, Kaul 1989), but represent different dune formations, geographic positions, and climatic regimes within the Sandhills (Bleed and Flowerday 1989). The study areas at Arapaho Prairie have not been grazed since 1978, whereas those at the Niobrara Valley Preserve were moderately grazed by cattle.

Protocol. We used a stratified random sampling regime to select large rosettes of each species in each of the 2 sites in early May, from 1990 to 1996 ( $n \geq 10$ per site; Table 1). Within each site, the plants were divided equally between 2 areas, separated by $>300 \mathrm{~m}$. All large rosettes encountered on walking transects through an area were included, up to the sample size required, if they met the $a$ priori criterion that there was at least $1 \mathrm{~cm}$ of stem, providing evidence that the plant would flower within the season. Initial data for each plant included: plant size, insect occurrence, and evidence of insect feeding. Evidence of insect feeding included: insect presence, oviposition scars, phyllary scarring and discoloration, characteristic head malformations, and frass (Louda and Potvin 1995, Stanforth et al. 1997). Plants were remeasured monthly: early season (late May), when $R$. conicus adults were active and most Platte thistle individuals had started flowerhead development; midseason (mid- to late June), as most flowerheads of Platte thistle finished flowering; late season (mid-July), after most Platte thistle seed had been released; and end of season (late August) for latest flowering individuals, predominantly wavyleaf thistle.

Mature flowerheads were collected after measurement. Flowerheads that had flowered but were not yet mature were covered with nylon mesh to prevent seed release prior to the next sampling date. All heads that flowered and large buds ( $>14 \mathrm{~mm}$ diameter) that developed were collected and dissected. Data from these heads included diameter, numbers of seeds and insects, and insect damage to the receptacle. Methods were based on published work (Kok and Surles 1975; Rees 1977, 1982; Surles and Kok 1978; Louda and Potvin 1995). 
Table 1. Sample sizes for quantification of R. conicus on Platte (C. canescens) and Wavyleaf (C. undulatum) thisles in 2 Sandhills prairie preserves in Nebraska

\begin{tabular}{|c|c|c|c|c|c|c|c|}
\hline \multicolumn{8}{|l|}{ Araphaho Prairie Preserve } \\
\hline Heads dissected (no.) & 48 & 47 & 51 & 76 & 102 & 120 & 100 \\
\hline \multicolumn{8}{|l|}{ Niobrara Valley Preserve } \\
\hline Plants sampled (no.) & 28 & 14 & 10 & 22 & 11 & 23 & 42 \\
\hline \multicolumn{8}{|l|}{ Arapaho Prairie Preserve } \\
\hline Plants sampled (no.) & 19 & 15 & 10 & 11 & 9 & 13 & 10 \\
\hline Heads dissected (no.) & 30 & 37 & 49 & 47 & 46 & 45 & 26 \\
\hline \multicolumn{8}{|l|}{ Niobrara Valley preserve } \\
\hline Plants sampled (no.) & 20 & 22 & 10 & 10 & 10 & 12 & $1 \tilde{5}$ \\
\hline Heads dissected (no.) & 48 & 57 & 44 & 24 & 30 & 34 & 28 \\
\hline
\end{tabular}

Descriptive statistics, plus 1-way analysis of variance (ANOVA) of square root-transformed counts, were used to present and evaluate the patterns in key variables (Wilkinson 1986).

\section{Results}

The data show that host range expansion by $R$. conicus onto both native thistle species at these sites occurred in 1993, and that population growth on the native thistle accelerated from 1993 up to the writing of this report. Three types of evidence are available. First, no flowerhead weevils were recorded on or in flowerheads in $16 \mathrm{yr}$ of observation before 1993. Inflorescence-feeding by insects on Platte thistle, C. canescens, has been studied at Arapaho Prairie since 1977 (Lamp and McCarty 1979, 1982a, b; Louda and Potvin 1995) and on both thistles at the Niobrara Valley Preserve since 1990 (Table 1; unpublished data).

Second, adult $R$. conicus were first observed feeding and ovipositing on Platte thistle at Arapaho Prairie in May 1994 and at Niobrara Valley in May 1995 (Fig. 1A; Table 1). Numbers and densities of adults observed increased dramatically at both sites, with a 1-yr lag at the more northerly Niobrara Valley Preserve (Fig. 1A). The increase in adult weevil densities per plant was significant over the $7 \mathrm{yr}$ from 1990 to 1996 (1-way ANOVA, square root-transformed counts per plant, both at Arapaho $(F=2.21 ; \mathrm{df}=6,122 ; P<0.05)$ and at Niobrara $(F=3.49$; df $=6$, 134; $P<0.003)$.

Use of thistles by adult $R$. conicus was strongly aggregated. The variance-to-mean ratio from 1994 to 1996 averaged 8.4 at Arapaho Prairie and 11.9 at the Niobrara Valley Preserve, whereas the coefficients of variation averaged 3.4 and 3.7 , respectively. On Platte thistle, all of the adult $R$. conicus observed in 1996 occurred on only $23 \%$ of the 31 plants sampled at Arapaho Prairie and on only $27 \%$ of the 42 plants sampled at the Niobrara Preserve. The mechanism underlying the aggregation is unknown.

Third, in 1993 immature weevils were first encountered within dissected flowerheads of both species of native thistles at both sites (Fig. 2 A and B; Table 1). Evidence of weevil feeding within flowerheads in- creased exponentially on Platte thistle at Arapaho Prairie from 1993 to 1995 and at Niobrara Valley Preserve from 1993 to 1996 (Fig. 1B). In 1995, the number of weevils that developed in sampled flowerheads of Platte thistle was much higher at Arapaho Prairie in the southwestern Sandhills than at Niobrara Valley in the northcentral Sandhills, both per head (Fig. 1B) and per plant (Fig. 2A). Numbers were similar in 1996. Significantly fewer weevils were found in flowerheads of wavyleaf thistle than those of Platte thistle in both 1995 and $1996(P<0.001$; Fig. 2 A and B).

Could flowering phenology help explain the greater use of Platte thistle than of wavyleaf thistle by $R$ conicus? Platte thistle initiated flowerhead development between 3 and $4 \mathrm{wk}$ earlier than did wavyleaf thistle (Fig. 3), peaking in late May to early June. Flowering for wavyleaf peaked in late June to early July (Fig. 3). So, in late May when adult $R$. conicus weevils were common (Fig. 1A), the number of small flowerheads in the most susceptible size class was greater on Platte thistle than on wavyleaf thistle (Fig. 3)

\section{Discussion}

Population Growth. The data here document the beginning of the host range expansion by $R$. conicus on 2 native species, the initial rapid population growth on Platte thistle (Fig. 1), and slower growth on wavyleaf thistle (Fig. 2). The host range expansion by $R$. conicus here occurred after a quiescent period of population dispersal and buildup, $20 \mathrm{yr}$ after introduction. Despite extensive study, no $R$. conicus were found on Platte thistle 1977-1992 (Lamp and McCarty 1979, 1982a, b; Louda et al. 1990, 1992; Louda and Potvin 1995; Figs. 1 and 2A). A similar lag has been reported for population growth by other newly introduced insects (Andres and Goeden 1971, Goeden 1978b). The mechanism underlying the lag is not known.

The significant increase in the numbers of $R$. conicus on Platte thistle (Figs. 1 and 2A) was unexpected, based on the interpretation of prerelease studies (Zwoelfer and Harris 1984). And, based on the existing data for this system, this increase is likely to have a 

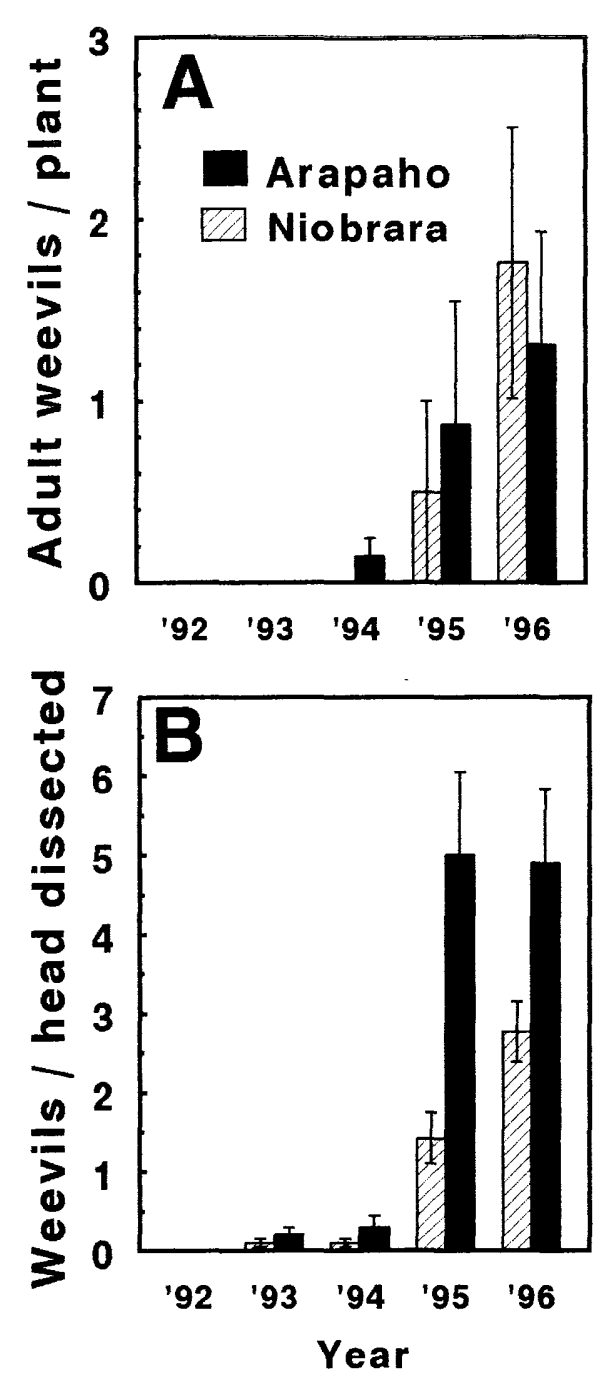

Fig. 1. Density (mean + SEM) of $R$. conicus on Platte thistle (C. canescens) at the Niobrara Valley Preserve and the Arapaho Prairie Preserve in central Nebraska sandhills prairie grassland, 1991-1996 (none seen 1984-1990; sample sizes, Table 1). (A) Number of adults observed per plant in late May. (B) Number of pupae or pupal cases developing per flowerhead (all heads $>14 \mathrm{~mm}$ diameter) by the end of plant growth in mid-July.

large, negative impact on the abundance of Platte thistle. In 1996, the weevil further reduced seed production over that caused by the native insects (Louda et al. 1997), and seed was already limiting (Louda and Potvin 1995). Also, the use of Platte thistle by $R$. conicus was highly aggregated, differentially affecting some plants more than others. Thus, $R$. conicus potentially represents a new selection pressure on the reproductive traits of Platte thistle. Furthermore, theory suggests that such aggregation, which increases in variability of fitness among individuals, can have a destabilizing effect on population persistence (Redfern and Pimm 1988).
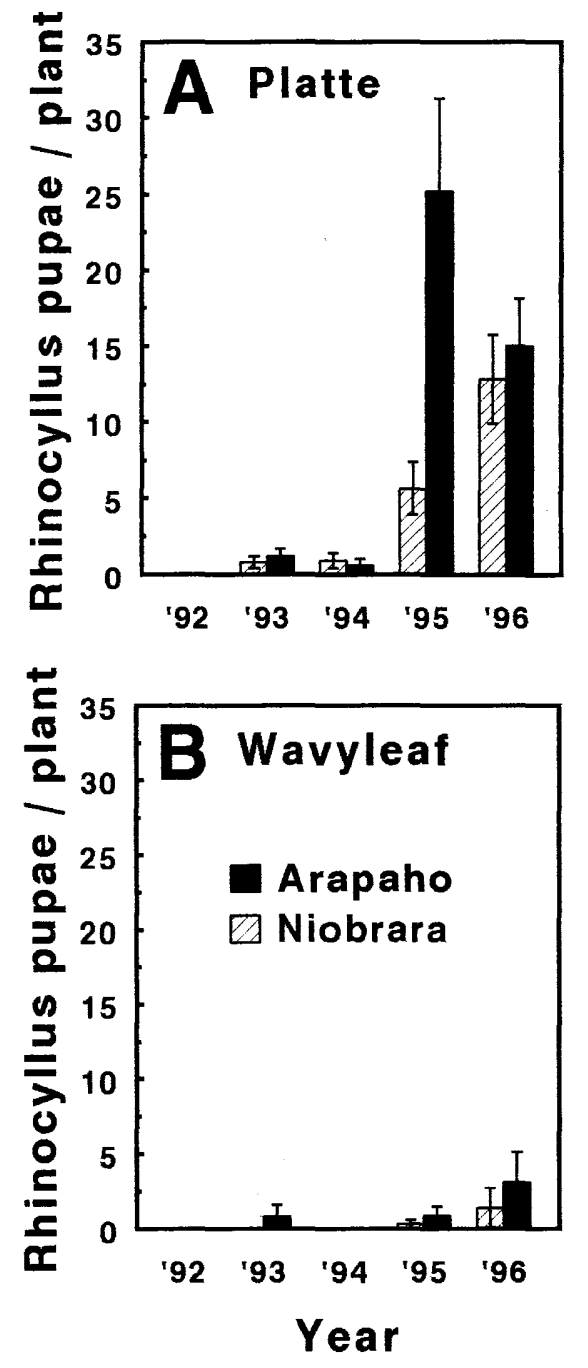

Fig. 2. Density (mean + SEM) per plant of R. conicus pupae or pupal cases developing within flowerheads $>14 \mathrm{~mm}$ diameter at Niobrara Valley Preserve and Arapaho Prairie Preserve in the Sandhills of Nebraska, 1991-1996 (sample sizes, Table 1). (A) Platte thistle (C. canescens). (B) Wavyleaf thistle (C. undulatum).

Ecological Correlates. Several aspects of these results are surprising, and potentially highly informative for our understanding of the population dynamics of insect-plant interactions. First, phenological synchrony between insect activity and potential plant resources appears important to the prediction of the intensity of nontarget host plant use. The 2 overlapping native species of thistles were differentially susceptible to population expansion by $R$. conicus (Fig. 2 ). Platte thistle flowerheads were used more heavily than those of wavyleaf thistle. And, flowerhead development of Platte thistle was better synchronized with the occurrence of ovipositing $R$. conicus adults (Fig. 1A) than was that of wavyleaf thistle (Fig. 3). In 


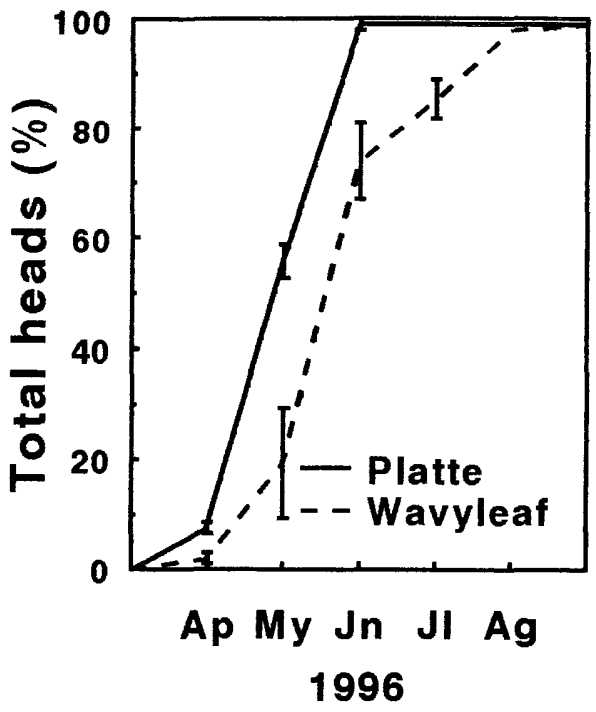

Fig. 3. Flowering phenology in 1996 of Platte thistle (C canescens) and Wavyleaf thistle (C. undulatum), in Niobrara Valley Preserve and Arapaho Prairie Preserve) in Sandhills prairie, Nebraska, presented as average cumulative percent of the total number of flowerheads reaching anthesis.

fact, the timing of inflorescence development of Platte thistle (Fig. 3) is very similar to that of Musk thistle (Kok and Surles 1975, McCarty and Lamp 1981). Thus, the coincidence of flowerhead development of Platte thistle with the oviposition period of $R$. conicus represents a likely mechanism to explain the relative vulnerability of the 2 native, nontarget Cirsium thistles at the study sites.

The importance of phenological synchrony in determining the magnitude of flower and seed consumption by insects has been proposed previously. Klein and Seitz (1994) found that the synchrony of plant flowering with the oviposition period of $R$. conicus in Europe, where the weevil is native, predicted its pattern of host plant use. Also, several studies suggest that different climatic conditions in new areas may alter relative phenologies of host and agent and so influence the impact of an agent on the seed production of its target weed (Goeden 1978a, Smith et al 1984, Youssef and Evans 1994, Briese 1996). For example, Goeden and Ricker (1985) found that the most likely explanation for the minimal control exerted by $R$. conicus on Carduus pycnocephalus L. in southern California was its lack of synchrony with its target plant there. The data in this study (Figs. 2 and 3 ) are consistent with the hypothesis that phenological synchrony is a critical determinant of the level of nontarget host range use by $R$. conicus. Experiments to directly test this hypothesis are underway.

Second, 2 important points on the dynamics of the invasion emerge. The transfer to the native thistles and the rapid population growth of $R$. conicus on Platte thistle occurred similarly on separated, very differently managed prairies. Thus, it is clear that disturbance, such as grazing, is not a necessary component in the host range expansion by an invasive insect. The population growth of $R$. conicus was actually faster on Platte thistle within the ungrazed site, Arapaho Prairie, than within the grazed site, Niobrara Valley (Fig. 2 ). Also, both preserves were isolated from areas with high musk thistle densities (Coffin 1995; unpublished data). Thus, proximity to and numerical build-up on populations of the primary, targeted host plant are not necessary for host range expansion onto phylogenetically related native, nontarget species.

Third, given the unique circumstance of extensive prior studies, the ecological consequences of the build-up of $R$. conicus on Platte thistle can be immediately evaluated quantitatively. The data suggest that the addition of this effective inflorescence-feeding insect will reduce plant abundance significantly. $\mathrm{Na}-$ tive inflorescence-feeding insects already limit seed production (Lamp and McCarty 1982a, b; Louda et al. 1990, 1992; Louda and Potvin 1995). And, seeds already limit both density and lifetime fitness (Louda and Potvin 1995). Feeding by $R$. conicus further reduced seed by 85.9\% in 1996 (Louda et al. 1997). Based on these relationships, a proportionate decrease in Platte thistle population density can be predicted. Also, because the distribution of Platte thistle is relatively limited compared with that of wavyleaf thistle, smaller local populations and aggregated attack within them may also negatively influence the probability of species persistence. Finally, the buildup of $R$. conicus on Platte thistle also appears to have had a negative effect on the most closely overlapping native insect, the tephritid $P$. culta. Fly densities declined at high weevil densities (Louda et al. 1997; unpublished data). Interestingly, $R$. conicus had a similar negative effect upon the tephritid Urophora solstitialis L. when both were introduced to control Carduus nutans L. in Australia (Woodburn 1996).

Implications for Biological Control. Control of invasive, exotic weeds is an important environmental issue (DeBach and Rosen 1991; OTA 1993, 1995). Classical biological control of weeds with their natural enemies represents a possible management tool (Kauffman and Nechols 1992; Louda and Masters 1993; OTA 1993, 1995; Guretzky and Louda 1997). However, there are important, unresolved issues surrounding the deliberate introduction of exotic insects. This study suggests that more ecological criteria are needed in prerelease screenings of potential biocontrol agents. Also, additional quantitative, follow-up studies of the population dynamics and impact of already released insects are needed, particularly where introduced insects are known to feed upon nontarget plant species. For example in the United States, Tyria jacobaeae L. (Lepidoptera: Arctiidae), released to control tansy ragwort, Senecio jacobaea L., in the Pacific northwest (Hawkes 1968, McEvoy et al. 1993), also feeds on the native Senecio triangularis Hooker in Oregon (Diehl and McEvoy 1990). And, the Argentine moth Cactoblastis cactorum Bergius (Lepidoptera: Pyralidae), used as a biocontrol agent for cacti worldwide (Goeden et al. 1967), is feeding on the few remaining individuals of an endangered subspecies of 
semaphore cactus, Opuntia spinosissima (Martyn) Miller in Florida (Simberloff 1992, Simberloff and Stiling 1996). Such situations represent opportunities to improve our understanding of risks.

Rhinocyllus conicus, in particular, presents an important case. Although it might not qualify for release now, it was screened carefully, and it was considered to be a safe, adequately specific biocontrol agent (Zwoelfer and Harris 1984). Although host transfer was recognized as an possibility, Zwoelfer and Harris (1984) used feeding trials and field observations to argue that $R$. conicus use and impact on native species would be very limited. They expected that higher abundances of preferred target host (Carduus spp.), compared with nontarget species, would curtail use of nontarget North American Cirsium spp. by R. conicus. And, slowed development and lower fecundity of $R$ conicus observed under the test conditions on the native Cirsium sp. tested (C. undulatum) were expected to exert strong selection against weevils that used native species, further limiting any impact of $R$. conicus on nontarget plants. However, weevil use of North American Cirsium spp. has been much more extensive and damaging than anticipated (e.g., Goeden and Ricker 1986a, b, 1987a, b; Turner et al. 1987; Louda et al. 1997).

Why are the results, including those presented here showing differential use of overlapping native species and exponential growth and high densities of $R$. conicus on Platte thistle, so different from those expected? The most likely explanation is that critical ecological questions, including those about plant flowering synchrony with weevil activity, were not addressed in the prerelease assessments of risk. This study highlights at least 2 questions that should have been answered. First, were prerelease tests using wavyleaf thistle, the species on which $R$. conicus population growth was lower and slower (Fig. 2), sufficient to evaluate the potential range of nontarget host use and effect? Because flowerheads of wavyleaf generally develop later than Musk or Platte thistles, it is not surprising that the probability of significant use by $R$. conicus on a more temporally synchronized native species was underestimated. Second, after colonization what outcome should be expected for palatable native species when the preferred target plant species is absent or significantly reduced? Little research has focused on risks to potentially acceptable native plants, or their dependent species, in the absence of the preferred target species after the naturalization of an exotic insect such as $R$. conicus.

In retrospect, neither the use of native Cirsium spp. in the absence of the targeted Carduus spp. nor the role of phenological synchrony in host preference between 2 co-occurring native thistles is surprising. In the absence of the preferred host, a less preferred species will be vulnerable. And, the coincidence of a potentially limiting resource, such as flowerheads for a flowerhead-feeding insect, with the period of insect activity that determines its distribution on the resource should be expected to influence level of use and impact. Prerelease studies of potential biocontrol insects generally do not include this type of ecological information in the assessment of risk. The choice of potential plant hosts to evaluate for risk now focuses on economic plants and phylogenetically related rare native species. The study clearly illustrates that more ecological criteria should be used to identify additional potentially vulnerable native species for prerelease assessment of ecological risks posed of potential agents. Also, additional long-term studies of the impact and side effects of insects already released will also provide information that should improve the selection of agents with reduced risk in the future.

\section{Acknowledgments}

I am grateful for the support and encouragement of the staff of the Nebraska Chapter of The Nature Conservancy, especially Mike Behrens, Richard Eglehoff, Duane Johnson, Doug Kuhre and Al Steuter as well as the staff of Cedar Point Biological Station, the taxonomic advice on weevil identity by Charlie O'Brien and, the competent and cheerful assistance of my students, especially Rob Bevill, Nate Brandt, Jutta Burger, Kelly Farrell, Mitch Gonzales, Amy Hines, Terri Tesar Huettner, Kathy Jackson, Sheri Jedlicka Arevalo, Sara McLaughlin, Shannon McNeil, Cheryl Murphy, Matt Paulsen, Matt Ramspott, Paul Renaud, Lynn Stanforth, Kim Stormburg, Brian Trainer and Mark Vejvoda. I also appreciate the field assistance, helpful discussions, or insightful comments on earlier drafts contributed by my colleagues, including Alex Basolo, Paul Boldt, Laurel Fox, Andre Gassmann, Tony Joern, Simon Mole, Julie Mulroy, Jim Nechols, Dennis O'Dowd, Rod Otley, Bob Pemberton, Diana Pilson, Al Steuter, Charley Turner, 2 anonymous reviewers, and especially my mother, Svata A. Louda, who contributed field assistance, editorial advice, and a lifetime of encouragement. The work could not have been done without the financial support of the University of Nebraska Research Council and The National Science Foundation (DEB9221065, DEB96-15299).

\section{References Cited}

Andres, L., and R. D. Goeden. 1971. The biological control of weeds by introduced natural enemies, pp. 143-164. In C. B. Huffaker [ed.], Biological control. Plenum, New York.

Bleed, A., and C. Flowerday. 1989. An atlas of the Sand Hills. Resource Atlas No. 5. University of Nebraska, IANR, Lincoln, NE

Boldt, P. E., and J. A. Jackman. 1993. Establishment of Rhinocyllus conicus Froelich on Carduus macrocephalus in Texas. Southwest. Entomol. 18: 173-181.

Briese, D. T. 1996. Phylogeny: can it help us to understand host choice by biological weed control agents, pp. 63-70. In V. C. Moran and J. H. Hoffman [eds.], Proceedings, 9th International symposium on biological control of weeds, Stellenbosch, South Africa, 19-26 January 1996. University of Cape Town, Cape Town, South Africa.

Coffin, M. 1995. Nebraska noxious weeds, pp. 9-11. In A. R. Martin [ed.], Crop protection clinics, 1995 edition. University of Nebraska, Cooperative Extension, Institute of Agriculture and Natural Resources, Lincoln, NE.

DeBach, P., and D. Rosen. 1991. Biological control by natural enemies, 2nd ed. Cambridge University Press, Cambridge, UK. 
Diehl, J., and P. B. McEvoy. 1990. Impact of the Cinnabar moth (Tyria jacobaeae) on Senecio triangularis, a nontarget native plant in Oregon, pp. 119-126. In E. S. Delfosse [ed.], Proceedings, 7 th International Symposium on Biological Control of Weeds, Rome, Italy, 6-11 March 1988. Ministero dell Agricoltura e delle Foreste and CSIRO, Rome, Italy.

Goeden, R. D. 1978a. Biological control of weeds. pp. 357413. In Introduced parasites and predators of arthropod pests and weeds: a world review. Handbook 480. USDAARS, Washington, DC

1978b. Initial analysis of Rhinocyllus conicus (Froehlich) (Coleoptera: Curculionidae) as an introduced natural enemy of milk thistle (Silybum marianum [L.] Gaertner) and Italian thistle (Carduus pycnocephalus L.) in southern California, pp. 39-50. In Biological control of the genus Carduus in the US. USDA, Stoneville, MS

Goeden, R. D., and D. W. Ricker. 1985. Seasonal asynchrony of Italian thistle, Carduus pycnocephalus, and the weevil, Rhinocyllus conicus (Coleoptera: Curculionidae), introduced for biological control in southern California. Environ. Entomol. 14: 433-436.

1986a. Phytophagous insect faunas of the two most common native Cirsium thistles, C. californicum and C. proteanum, in southern California. Ann. Entomol. Soc. Am. 79: 953-962.

1986b. Phytophagous insect faunas of two introduced Cirsium thistles, C. ochrocentrum and C. vulgare, in southern California Ann. Entomol. Soc. Am. 79: 945-952.

1987a. Phytophagous insect faunas of native Cirsium thistles, C. mohavense, C. neomexicanum, and C. nidulum, in the Mojave Desert of southern California. Ann. Entomol. Soc. Am. 80: 161-175.

1987b. Phytophagous insect faunas of the native thistles, Cirsium brevistylum, C. congdonii, C. occidentale, and C. tioganum in southern California. Ann. Entomol. Soc. Am. 80: $152-160$.

Goeden, R. D., C. A. Fleschner, and D. W. Ricker. 1967. Biological control of prickly pear cacti on Santa Cruz Island, California. Hilgardia 38: 579-606.

Great Plains Flora Association. 1977. Atlas of the flora of the Great Plains. Iowa State University Press, Ames.

1986. Flora of the Great Plains. University Press of Kansas, Lawrence, $\mathrm{KS}$.

Guretzky, J. A., and S. M. Louda. 1997. Evidence for naturally-occurring biological control: reduction of the survival and growth of Cirsium altissimum. Ecol. Appl. 7 $1330-1340$.

Hawkes, R. B. 1968. The cinnabar moth, Tyria jacobaeae, for control of tansy ragwort. J. Econ. Entomol. 61; 499-501.

Howarth, F. G. 1983. Classical biological control: panacea or Pandora's Box? Proc. Hawaii. Entomol. Soc. 24: 239 244.

1991. Environmental impacts of classical biological control Annu. Rev Entomol 36: 485-509.

Karieva, P. M. 1996. Contributions of ecology to biological control. Ecology 77: 1963-1664.

Kauffman, W. C., and J. R. Nechols [eds.]. 1992. Selection criteria and ecological consequences of importing natural enemies. Entomological Society of America, Lanham, MD.

Kaul, R. 1989. Plants, pp. 127-142. In A. Bleed and C. Flowerday [eds.], An atlas of the Sand Hills. Resource atlas 5 Conservation and Survey Division, Institute of Agriculture and Natural Resources, University of Nebraska, Lincoln.

Keddy, C. J., and P. A. Keddy. 1984. Reproductive biology and habitat of Cirsium pitcheri. Mich. Bot. 23: 57-67.
Keeler, K. H., A. T. Harrison, and L. Vescio. 1980. The flora and Sand Hills prairie communities of Arapaho Prairie, Arthur County, Nebraska. Prairie Nat. 12: 65-78.

Klein, M., and A. Seitz. 1994. Geographic differentiation between populations of Rhinocyllus conicus Froelich (Coleoptera: Curculionidae): concordance of allozyme and morphometric analysis. Zool. J. Linn. Soc. 110: 181-191.

Kok, L. T., and W. W. Surles. 1975. Successful biocontrol of Musk thistle by an introduced weevil, Rhinocyllus conicus. Environ. Entomol 4:1025-1027.

Lamp, W. O., and M. K. McCarty. 1979. A preliminary study of seed predators of Platte thistle. Trans. Nebr. Acad. Sci. 7: 71-74.

1981. Biology and ecology of Platte thistle (Cirsium canescens). Weed Sci. 29: 686-692.

1982a. Biology of predispersal seed predators of the Platte thistle, Cirsium canescens. J. Kan. Entomol. Soc. 55: 305316.

1982b. Predispersal seed predation of a native thistle, $\mathrm{Cir}$ sium canescens. Environ. Entomol. 11: 847-851.

Louda, S. M. 1994. Experimental evidence for insect impact on populations of short-lived, perennial plants, and its application in restoration ecology, pp. 118-138. In M. L. Bowles and C. J. Whelan [eds.], Restoration of endangered species. Cambridge University Press, Cambridge. UK

Louda, S. M., and R. Masters. 1993. Biological control of weeds in Great Plains rangelands. Great Plains Res. 3: 167-199.

Louda, S. M., and M. A. Potvin. 1995. Effect of inflorescence-feeding insects in the demography and lifetime fitness of a native plant. Ecology 76: 229-245.

Louda, S. M., M. A. Potvin, and S. K. Collinge. 1990. Predispersal seed predation, postdispersal seed predation and competition in the recruitment of seedlings of a native thistle in sandhills prairie. Am. Midl. Nat. 124: 105-113.

1992. Predispersal seed predation in the limitation of native thistle, pp. 30-32. In S.B.J. Menken, J. H. Visser and P. Harrewijn [eds.], Insect-plant relationships. Kluwer, Dordrecht, The Netherlands.

Louda, S. M., D. Kendall, J. Conner, and D. Simberloff. 1997. Ecological effects of an insect introduced for the biological control of weeds. Science (Wash. D.C.) 277: 1088 1090.

McCarty, M. K., and W. O. Lamp. 1982. Effect of a weevil, Rhinocyllus conicus, on Musk Thistle (Carduus thoermeri) seed production. Weed Sci. 30: 136-140.

McCarty, M. K., C. J. Scifres, and L. R. Robinson. 1967. A descriptive guide for major Nebraska thistles. SB 493. University of Nebraska, College of Agriculture, Lincoln.

McEvoy, P. B. 1996. Host specificity and biological pest control. BioScience 46: 401-405.

McEvoy, P.B., N. T. Rudd, C. S. Cox, and M. Huso. 1993. Disturbance, competition, and herbivory effects on ragwort, Senecio jacobaea, populations. Ecol. Monogr. 63: $55-75$.

[OTA] Office of Technology Assessment, United States Congress. 1993. Harmful non-indigenous species in the United States. OTA-F-ð65, September 1993. U.S. Government Printing Office, Washington, DC.

1995. Biologically based technologies for pest control. OTA-ENV-636, September 1993, U.S. Government Printing Office, Washington, DC.

Palmisano, S., and L. R. Fox. 1997. Effects of mammal and insect herbivory on population dynamics of a native $\mathrm{Cal}$ ifornian thistle, Cirsium occidentale. Oecologia (Berl.) 111: 413-421. 
Pavlovic, N. B., M. Bowles, S. R. Crispin, T. C. Gibson, K. D. Herman, R. T. Kavetsky, A. K. McEachern, and M. R. Penskar. 1992. Pitcher's thistle (Cirsium pitcheri) recovery plan. U.S. Fish and Wildlife Service (Region 3), Department of the Interior, Minneapolis, MN.

Pemberton, R. W., C. E. Turner, and S. S. Rosenthal. 1985. New host records for tephritid flies (Diptera) from Cirsium and Saussurea thistles (Asteraceae) in California. Proc. Entomol. Soc. Wash. 87: 790-794.

Redfern, A., and S. L. Pimm. 1988. Population variability and polyphagy in herbivorous communities. Ecol. Monogr. 58: 39-55.

Rees, N. E. 1977. Impact of Rhinocyllus conicus on thistles in southwestern Montana. Environ. Entomol. 6: 839-842.

1982. Collecting, handling and releasing Rhinocyllus conicus, a biological control agent of musk thistle. U.S. Agric. Res. Serv. Tech. Bull. 579 .

1991. Biological control of thistles, pp. 264-273. In L. F James, J. O. Evans, M. H. Ralphs, and R. D. Child [eds.], Noxious range weeds. Westview, Boulder, $\mathrm{CO}$

Simberloff, D. 1981. Community effects of introduced species, pp. 53-81. In T. H. Nitecki [ed.], Biotic crises in ecological and evolutionary time. Academic, New York.

1992. Conservation of pristine habitats and unintended effects of biological control, pp. 103-117. In W. C. Kauffman and J. E. Nechols [ed.], Selection criteria and ecological consequences of importing natural enemies. Entomological Society of America, Lanham, MD.

Simberloff, D. and P. Stiling. 1996. How risky is biological control? Ecology 77: 1965-1974.

Smith, L. M., F. W. Ravlin, L. T. Kok, and W. T. Mays. 1984. Seasonal model of the interaction between Rhinocyllus conicus (Coleoptera: Curculionidae) and its weed host Carduus thoermeri (Campanulatae: Asteraceae). Environ. Entomol. 13: 1417-1426.

Stanforth, L. M., S. M. Louda, and R. L. Bevill. 1997. Insect herbivory on juveniles of a threatened plant, Cirsium pitcheri, in relation to plant size, density and distribution EcoScience 4: 57-66.

Surles, W. W., and L. T. Kok. 1978. Carduus thistle seed destruction by Rhinocyllus conicus. J. Weed Sci. Soc. Am. 26: 264-269.

Turner, C. E., and J. C. Herr. 1996. Impact of Rhinocyllus comicus on a non-target, rare, native thistle (Cirsium fontinale) in California, p. 103. In V. C. Moran and J. H. Hoffmann [eds.], Proceedings, 9th International Symposium on Biological control of Weeds. University of Cape Town, Cape Town, South Africa (abstr.).

Turner, C. E., R. W. Pemberton, and S. S. Rosenthal. 1987. Host utilization of native Cirsium thistles (Asteraceae) by the introduced weevil Rhinocyllus conicus (Coleoptera: Curculionidae) in California. Environ. Entomol. 16: 111115 .

Wilkinson, L. 1986. SYSTAT, the system for statistics. SYSTAT, Evanston, IL.

Woodburn, T. L. 1996. Interspecific competition between Rhinocyllus conicus and Urophora solstitialis, two biocontrol agents released in Australia against Carduus nutans, pp. 409-415. In V. C. Moran and J. H. Hoffmann [eds.], Proceedings, 9th International Symposium on Biological control of Weeds, Stellenbosch, South Africa, 19-26 January 1996. University of Cape Town, Cape Town, South Africa.

Youssef, N. N., and E. W. Evans. 1994. Exploitation of Canada thistle by the weevil Rhinocyllus conicus (Coleoptera: Curculionidae) in Northern Utah. Environ. Entomol. 23: 1013-1019

Zwoelfer, H., and P. Harris. 1984. Biology and host specificity of Rhinocyllus conicus (Froel.) (Col., Curculionidae), a successful agent for the biocontrol of the thistle, Carduus nutans L. Z. Angew. Entomol. 97: 36-62.

Received for publication 11 April 1997; accepted 29 December 1997 . 